\title{
Comparison and toxicity assessment of co-composting process by pistachio wastes and date-palm straw combined with municipal sewage sludge
}

Habibe Jafariniya Parizi

Shahid Sadoughi University of Medical Sciences and Health Services

Mehdi Mokhtari

Shahid Sadoughi University of Medical Sciences and Health Services

Hadi Eslami ( $\sim$ hadieslami1986@yahoo.com)

Rafsanjan University of Medical Sciences https://orcid.org/0000-0001-5137-4764

Farzan Madadizadeh

Shahid Sadoughi University of Medical Sciences and Health Services

Mahrokh Jalili

Shahid Sadoughi University of Medical Sciences and Health Services

Mohammad Mobini

Rafsanjan University of Medical Sciences

Abdolreza Nassab Hosseini

Rafsanjan University of Medical Sciences

Ali Asghar Ebrahimi ( $\nabla$ ebrahimi20007@gmail.com)

Shahid Sadoughi University of Medical Sciences and Health Services

\section{Research Article}

Keywords: Co-composting, Pistachio Waste, Palm Straw, Municipal Sewage Sludge

Posted Date: June 8th, 2021

DOI: https://doi.org/10.21203/rs.3.rs-499610/v1

License: (9) This work is licensed under a Creative Commons Attribution 4.0 International License. Read Full License

Version of Record: A version of this preprint was published at Biomass Conversion and Biorefinery on April 5th, 2022. See the published version at https://doi.org/10.1007/s13399-022-02563-5. 


\section{Abstract}

This study aimed to toxicity evaluate and compare the new co-composting process of pistachio dehulling waste combined with municipal sewage sludge (PW + SS) and date-palm straw combined with municipal sewage sludge (PS + SS). The process was evaluated over a 60-day period. During the process, physicochemical parameters (temperature, humidity, pH, electrical conductivity $(\mathrm{EC})$, carbon to nitrogen ratio $(\mathrm{C} / \mathrm{N})$, ash and organic carbon $(\mathrm{OC})$ ), microbial indicators (parasite eggs, salmonella, $E$. coli), heavy metals (copper, zinc, Iron, manganese, lead, cadmium, nickel), and germination index were measured. The results showed that in the PW +SS reactor the maximum temperature reached $59^{\circ} \mathrm{C}$ on the 32th day and in the PS $+\mathrm{SS}$ reactor reached $39^{\circ} \mathrm{C}$ on 18th day. The $\mathrm{pH}$ level in PW $+\mathrm{SS}$ reached a minimum of 3.2 on the 14 th day and then increased and finally reached a maximum of 9.5. The $\mathrm{pH}$ level in PS + SS had an increasing trend and finally reached 7.1. Ash percentage had an increasing trend in PW + SS and finally reached 27.5 and reached 19.1 in PS + SS $(p=0.038)$. EC, C/N and OC in both reactors had a significant decreasing trend. E. coli microbial indicator in both reactors decreased from $\geq 10^{5}$ to zero at the end of the process. The amounts of heavy metals in both reactors had an increasing trend and were within the standard range. Toxicity assessment showed that the PS + SS compost was 100\% in all concentrations and the PW + SS compost reached 100\% by dilution; therefore, the product of PS + SS was less toxic than the product of PW + SS.

\section{Introduction}

In recent years, there has been a significant increase in the production of various wastes, which has increased the production of pollutants and created a worrying situation for public health and the global environment (Esmaeili et al. 2020). With the everincreasing global demand for food, global grain production will increase by about $50 \%$ by 2050 , leading to the production of large quantities of residues (Ajmal et al. 2020). According to the Food and Agriculture Organization (FAO), about 1.3 billion tons of food waste or garbage is disposed at landfills each year. Food waste is typically low in calories, high in water, and highly perishable (Ajmal et al. 2020). Biodegradable waste is the main part of municipal waste and can cause significant environmental hazards if not treated properly (Girón-Rojas et al. 2020). Disposal of organic waste by landfill and incineration may cause serious environmental problems, such as gas emissions (Zhou et al. 2019). Every year, due to the increase in agricultural activities to meet world's growing demand for food, there is a significant increase in waste production in the agricultural sector (Sahu et al. 2020). The Middle East is the largest producer of dates in the world, and after Iraq, Saudi Arabia, and Egypt, Iran is the fourth largest producer of this food in this region. In order to harvest dates with good quality, palms should be pruned every year and the waste from each palm is on average about $17-34 \mathrm{~kg}$. Large volumes of this waste are incinerated. On the other hand, using agricultural waste in order to protect the environment is of great importance (Shirani et al. 2011). According to the available statistics in Iran, due to the lack of conversion industries, half of the agricultural products are destroyed (Zhao et al. 2015). The volume of pistachio production in Iran is more than 575 thousand tons at each year (Jalili et al. 2016). Kerman province is one of the arid and semi-arid regions of Iran with poor soils in terms of organic matter and the main pole of one of the most important agricultural products, namely pistachios. After harvesting pistachio crops, its waste is left which has no economic value (Esmaeili et al. 2020). Pistachio dehulling waste due to its high perishability, if not disposed of hygienically, will cause environmental pollution (Ahanchi et al. 2018). Using continuous chemical fertilizers in agricultural lands, by changing the properties of the soil, leads to soil contamination and soil contamination in turn causes erosion of agricultural lands (Geethamani et al. 2020). Sewage sludge contains valuable sources of organic matter and nutrients (Rashad et al. 2010). Composting is a very acceptable method for converting organic waste into a sustainable product that is non-toxic and nonpathogenic and can be used as a suitable fertilizer for plant growth (Toledo et al. 2020). The direct use of sewage sludge in agriculture has been limited due to the presence of pathogens, improper fermentation of organic waste and the presence of heavy metals, organic and inorganic contaminants in the sludge (Meng et al. 2020). Composting is an important and widely used method to convert fertilizer into a sustainable organic fertilizer and is an opportunity to close the gap between livestock and agricultural systems and reduce the risk of environmental pollution through managing livestock manure from the animal husbandry industry (Sahu et al. 2020). Co-composting of sewage sludge combined with other wastes is an important and vital technology leading to the reuse of wastes and also their safe and hygienic disposal. Production of compost from sewage sludge alone is of low quality due to its high humidity and low amount of organic carbon. Therefore, the applying sewage sludge compost alone is not a priority. Composting sewage sludge combined with animal waste and excrement as bulking agents began 
in France, Germany, Hungary and Japan. Later in northern Europe, Russia, and the United States from the early 1970s, sewage sludge was used to produce compost (Hu et al. 2011). The quality of the produced compost is evaluated by different techniques, but its stability and maturity are two basic aspects that should be examined before applying compost to the soil. Important parameters for evaluating compost maturity include temperature, $\mathrm{pH}$, electrical conductivity (EC), total nitrogen, total organic carbon, carbon to nitrogen ratio (C/N), germination index, and heavy metals content (Dhamodharan et al. 2019, Mudhoo et al. 2020). When the mixture to be composted contains thick or slow-digesting materials, such as pruning, it is important that the material be crushed to make the mixture homogeneous and increase its porosity. This increases the level of contact of microbes with organic matter and increases the amount of oxygen supply (Calisti et al. 2020). Malakotian et al, examined the co-compost of pistachio waste and poultry manure and concluded that it is within the standard range (Malakootian et al. 2014). Jalili et al, in their study, entitled "evaluation and comparison of pistachio dehulling waste combined with two treatments of municipal sewage sludge and cow manure" showed that both composts are within the standards of Iran and pistachio dehulling waste compost combined with cow manure has higher quality (Jalili et al. 2016).

Given the annual high volume production of pistachio waste, sewage sludge, and date-palm straw and their high management and disposal costs and also the need to protect the environment, the present study aimed to toxicity evaluate and compare the new co-composting process of pistachio dehulling waste combined with municipal sewage sludge (PW + SS) and date-palm straw combined with municipal sewage sludge (PS + SS).

\section{Materials And Methods}

\section{Preparing of co-composting reactor}

The present study was an experimental study conducted on pistachio processing waste and date-palm straw over a 60-day period. Pistachio processing waste and date-palm straw were obtained from farmers. Due to the large size of pistachio waste and date-palm straw, pistachio waste was crushed about $1 \mathrm{~cm}$ and date-palm straw about $0.5 \mathrm{~cm}$. The crushed waste was then combined with municipal sewage sludge. Dehydrated sludge was prepared from Sarcheshmeh wastewater treatment plant located in Rafsanjan, Iran operated with activated sludge system. The carbon to nitrogen ratio was considered in the range of 20-40. In each mass, for $4.5 \mathrm{~kg}$ municipal sewage sludge, $5 \mathrm{~kg}$ pistachio dehulling waste was added and for $8 \mathrm{~kg}$ sewage sludge, $2.8 \mathrm{~kg}$ date-palm straw was added. In the dehydrated sludge treatment, $300 \mathrm{~g}$ of wood chips was added as a bulking agent to increase the dehydration property and facilitate aeration. The samples were placed in a reactor after mixing. The weight of the mass containing the pistachio sludge treatment at the end of the process reached $2 \mathrm{~kg}$ and the date-palm straw reached 5 $\mathrm{kg}$. In this study, two cylindrical reactors made of compacted plastic with equal dimensions $\pi \mathrm{r}(10 \mathrm{~cm})^{2} \times \mathrm{h}(45 \mathrm{~cm})$ were used. At a height of $5 \mathrm{~cm}$ from the reactor floor, a net with $2 \mathrm{~mm}$ holes was installed to collect the produced leachate. A faucet was installed in the reactor floor to remove the leachate. The moisture content at the beginning of the process was $55 \%$ in PW + SS and $60 \%$ in PS + SS. To aerate the reactors, the air compressor (AQ908A, Aquatec, China) was turned on and off for 15 minutes and the required air in the two reactors was determined to be $0.4(\mathrm{~L} / \mathrm{min} / \mathrm{kg})$.

\section{Experimental analysis}

Before the tests, the materials were mixed inside the reactor and then sampling was performed. Physical and chemical tests (including temperature, $\mathrm{C} / \mathrm{N}$, humidity, $\mathrm{pH}, \mathrm{EC}$, heavy metals and $\mathrm{OC}$ percentage) and biological tests (including parasite eggs, $E$. coli, salmonella) were performed twice. To measure the percentage of moisture, carbon, organic carbon, and ash, first $5 \mathrm{~g}$ of the sample was taken and poured it into crucibles, then the crucibles were placed in the oven (Behdad, Iran) with a temperature of 103 to $105^{\circ} \mathrm{C}$. Then the dried sample was put in the Furnace (Behdad, Iran) at $550^{\circ} \mathrm{C}$ for 4 hours $(21,22)$. To measure pH and EC, $10 \mathrm{~g}$ of the sample was taken and mixed with $100 \mathrm{ml}$ of distilled water to obtain a suspension. Then it was passed through a $0.45 \mu$ filter and measured by pH meter (AZ Instrument, Taiwan) and to measure EC (GMH 3431, Greisinger electronic, Germany) was used. To measure nitrogen by Kjeldahl method, first $2 \mathrm{~g}$ of the sample was taken from the reactors and then digested. To perform the digestion process, salicylic acid and sulfuric acid were added to the sample and placed on a shaker for 40 min and then potassium thiosulfate was added. The prepared suspension was read by spectrophotometer model DR6000 $(\mathrm{HACH}$,

Germany). To measure the metals, they were stored at $103-105^{\circ} \mathrm{C}$ for 2 hours and nitric acid and phosphoric acid were added to them for digestion and then measured by atomic absorption spectrometer. For microbial analysis, after preparing the cultures for

Page $3 / 15$ 
fecal coliforms, the multi-tube fermentation method and A1 culture medium were used. In this method, different dilutions of 1 , 0.1 , and 0.01 were used, then the tubes were used in water bath conditions at $44.5^{\circ} \mathrm{C}$ for $20-24$ hours. Zinc sulfate solution was also used to measure the parasite eggs for preparing the suspension. First, sulfate solution was poured into half of the tube, then about $1 \mathrm{~g}$ of the sample was poured into the tube and the suspension was prepared using an applicator. The prepared suspension was passed through a double layer filter paper to filter the solution, then the filtered solution was returned to the tube and until the solution surface reached $2-3 \mathrm{~mm}$ of the tube mouth. The tube was placed in a centrifuge at $3000 \mathrm{rpm}$ for one minute. After centrifugation, it was placed under a microscope using a lam impregnated with lugol reagent. To measure the number of salmonella, some of the sample was first placed in peptone water medium and after 24 hours of incubation, in case of microbial growth in the medium, it was inoculated into Rappaport-Vassiliadis Salmonella Enrichment broth (RVS) and tetrathionate broth culture medium. After 24 hours, it was cultured in water bath in Salmonella Shigella (SS) Agar medium to inhibit bacterial species other than salmonella. The amount of salmonella was calculated as MPN/4g dry weight (Jalili et al. 2019).

\section{Toxicity Assessment (germination index)}

To measure the germination index, the compost was mixed with distilled water in a ratio of 1:5. It was placed on a shaker for 30 min to obtain a suspension, then passed through a filter paper. Ten $\mathrm{ml}$ of the suspension was poured into a sterilized plate (containing a piece of paper at the bottom of the plate) and 10 cress seeds were added and kept in the dark at $25^{\circ} \mathrm{C}$ for 48 hours. The number of germinated seeds was then counted and measured (Luo et al. 2018).

$\mathrm{GI}=\left(\mathrm{sg}_{\text {compost }}\right) /\left(\mathrm{sg}_{\text {water }}\right) \times 100$

$\mathrm{GI}=$ germination index

$\mathrm{sg}=$ number of germination indices

\section{Data analysis}

Mean, standard deviation, median, and interquartile range indices were used to perform descriptive statistics. To perform inferential statistics and compare quantitative study variables (including temperature, humidity, ash and OC percentage, $\mathrm{C} / \mathrm{N}, \mathrm{pH}$, EC, heavy metals, parasite eggs, salmonella, E. coli, germination index) in the two reactors (PW + SS and PS + SS) Mann-Whitney non-parametric test was used. All analyses were performed in SPSS software version 16 and the significance level in all tests was considered 0.05 .

\section{Results And Discussion}

The co-compost characteristics of PW + SS and PS + SS are given in Table 1. According to the results of Table 1, the changes of moisture, $\mathrm{C} / \mathrm{N}$, ash and $\mathrm{OC}$ percentage were statistically significant $(\mathrm{p}<0.05)$. There was no statistically significant difference in the other parameters. The results of microbiological tests also showed that the number of $E$. coli in the two reactors was $>10^{5}$, which had a decreasing trend during the process and reached zero in the final product. The number of parasite eggs and salmonella in both reactors in the initial raw mixture and final product after the process was zero. 
Table 1

Physicochemical and microbial parameters in co-composting process by $\mathrm{PW}+\mathrm{SS}$ and $\mathrm{PS}+\mathrm{SS}$ reactors

\begin{tabular}{|c|c|c|c|c|c|c|c|c|c|}
\hline \multirow[t]{2}{*}{ Parameter } & \multicolumn{4}{|l|}{ PS + SS } & \multicolumn{4}{|l|}{$P W+S S$} & \multirow{2}{*}{$\begin{array}{l}\mathrm{p} \text { - } \\
\text { value }\end{array}$} \\
\hline & $\begin{array}{l}\text { Mean } \pm \\
\text { standard } \\
\text { deviation } \\
\text { (initial) }\end{array}$ & Maximum & Minimum & $\begin{array}{l}\text { mature } \\
\text { compost } \\
\text { (final) }\end{array}$ & $\begin{array}{l}\text { Mean } \pm \\
\text { standard } \\
\text { deviation } \\
\text { (initial) }\end{array}$ & Maximum & Minimum & $\begin{array}{l}\text { mature } \\
\text { compost } \\
\text { (final) }\end{array}$ & \\
\hline $\begin{array}{l}\text { Humidity } \\
(\%)\end{array}$ & $\begin{array}{l}1.55 \pm \\
58.7\end{array}$ & 60 & 50 & 50 & $\begin{array}{l}4.73 \pm \\
50.1\end{array}$ & 55 & 40 & 40 & $\begin{array}{l}\mathrm{p}< \\
0.05\end{array}$ \\
\hline $\mathrm{pH}$ & $0.44 \pm 6.8$ & 7.2 & 6 & 7 & $1.98 \pm 7$ & 9.5 & 3.2 & 9.5 & $\begin{array}{l}p> \\
0.05\end{array}$ \\
\hline $\begin{array}{l}\mathrm{EC}(\mathrm{m} \\
\mathrm{mhose} / \mathrm{cm})\end{array}$ & $1.3 \pm 3.2$ & 6.2 & 2 & 2.3 & $\begin{array}{l}1.52 \pm \\
3.8\end{array}$ & 6.1 & 1.6 & 3.2 & $\begin{array}{l}p> \\
0.05\end{array}$ \\
\hline  & $3.96 \pm 32$ & 40 & 23.5 & 26 & $\begin{array}{l}10.42 \pm \\
37\end{array}$ & 59 & 17 & 27 & $\begin{array}{l}p> \\
0.05\end{array}$ \\
\hline Ratio $\mathrm{C} / \mathrm{N}$ & $\begin{array}{l}4.82 \pm \\
30.65\end{array}$ & 37 & 23 & 23 & $\begin{array}{l}4.07 \pm \\
18.65\end{array}$ & 24.5 & 13.26 & 13.26 & $\begin{array}{l}\mathrm{p}< \\
0.05\end{array}$ \\
\hline Ash (\%) & $\begin{array}{l}1.24 \pm \\
17.23\end{array}$ & 19.01 & 15.5 & 19.01 & $\begin{array}{l}4.18 \pm \\
21.3\end{array}$ & 27.5 & 16.32 & 27.5 & $\begin{array}{l}\mathrm{p}< \\
0.05\end{array}$ \\
\hline $\begin{array}{l}\text { Volatile } \\
\text { matter (\%) }\end{array}$ & $\begin{array}{l}12.14 \pm \\
61.9\end{array}$ & 77.47 & 47.6 & 47.6 & $\begin{array}{l}19.72 \pm \\
40.02\end{array}$ & 67.5 & 17 & 17 & $\begin{array}{l}\mathrm{p}< \\
0.05\end{array}$ \\
\hline E. Coli & $\begin{array}{l}41802.02 \\
\pm 31431.4\end{array}$ & $>100000$ & 0 & 0 & $\begin{array}{l}37351.7 \\
\pm \\
25715.7\end{array}$ & $>100000$ & 0 & 0 & $\begin{array}{l}p> \\
0.05\end{array}$ \\
\hline Salmonella & 0 & - & - & 0 & 0 & - & - & 0 & - \\
\hline $\begin{array}{l}\text { Parasite } \\
\text { eggs }\end{array}$ & 0 & - & - & 0 & 0 & - & - & 0 & - \\
\hline
\end{tabular}

\section{Temperature and humidity changes}

One of the important factors in composting and eliminating pathogens is temperature (Awasthi et al. 2015). Figure 1a reveals the temperature changes during the composting process of PW + SS and PS + SS reactors over a 60-day period. On the 2nd day of the process in both reactors, a significant increase in temperature occurred in the masses. This rate was higher in the PW + SS reactor than in the PS + SS reactor. The PS + SS reactor reached its maximum temperature on the 20th day $\left(40^{\circ} \mathrm{C}\right)$ and the $\mathrm{PW}+$ SS reactor reached its maximum temperature on the 32th day $\left(57^{\circ} \mathrm{C}\right)$. Then the temperature in the masses began to decrease, which on the 60th day reached $25^{\circ} \mathrm{C}$ in the PW $+\mathrm{SS}$ and $27^{\circ} \mathrm{C}$ in the PS $+\mathrm{SS}$. According to the changes shown in the figure, these changes were not statistically significant $(p=0.5)$ and the interquartile range for PW + SS and PS + SS reactors were 15.75 and 3.5, respectively. The temperature in the PW + SS reactor was better than the PS + SS reactor. The results of Shirani et al, regarding the evaluation and comparison of municipal composting and vermicomposting, showed that the temperature increase in the mass was good and organic matter decomposition was performed well (Shirani et al. 2011). Jalili et al, reported that in the pistachio dehulling waste and cow manure pilot, the temperature reached above $50^{\circ} \mathrm{C}$, corresponding to the pistachio dehulling waste reactor combined with municipal sewage sludge and in the pilot of pistachio dehulling waste and municipal sewage sludge, the temperature reached below $50^{\circ} \mathrm{C}$, corresponding to the municipal sewage sludge combined with the date-palm straw reactor (Jalili et al. 2016).

Another important factor in composting is moisture content. Figure $1 \mathrm{~b}$ shows the moisture changes during the composting process in the PW + SS and PS + SS reactors. In the PW + SS reactor, the moisture percentage was $55 \%$ and in the PS + SS reactor, due to the type of straw (due to the high lignocellulose content), a higher moisture content $(60 \%)$ was considered compared to the pistachio dehulling waste content (Usman et al. 2015). In a 60-day period, the moisture content in the PW + SS reactor decreased from $55-43 \%$ and in the PS + SS reactor the moisture content decreased from $60-54 \%$. The results showed that the 
PS + SS reactor needed more time to lose moisture. Due to the changes in humidity during the composting process in the two reactors, the moisture percentage decreased significantly $(p \leq 0.001)$ and the interquartile range for the PW $+S S$ and PS + SS reactors was 9.4 and 2.05, respectively. Xuejiang et al, evaluated the changes in humidity and temperature in the composting process by windrow method and concluded that the compost temperature reached $62^{\circ} \mathrm{C}$ and the humidity reached $35 \%$ on the 9th day (Xuejiang et al. 2008). Jalili et al, conducted a study on two pilots of composting pistachio dehulling waste combined with municipal sewage sludge and cow manure. They concluded that the appropriate humidity content to start the composting process was $50 \%$ and the cow manure reactor was in better condition than municipal sewage. To prevent fungus formation and better dehydrating, they added $15 \%$ by weight of sawdust, which is consistent with the results of the present study (Jalili et al. 2019).

\section{$\mathrm{PH}$ and EC changes}

Figure $2 \mathrm{a}$ shows the $\mathrm{pH}$ changes during the composting process in the PW + SS and PS + SS reactors. $\mathrm{pH}$ is affected by the raw materials used in the compost. As the process begins and bacterial activity increases, and organic acids are produced, the $\mathrm{pH}$ increases. $\mathrm{pH}$ of the PW + SS reactor reached 3 on the 14th day and then increased, and in the PS + SS reactor reached 7.2 on the 14th day and 6.6 on the 28th and had decreasing trend). Then, by entering the secondary mesophilic phase, the reactors $\mathrm{pH}$ increased. The final $\mathrm{pH}$ value in the PW + SS was 5.9 and in the PS + SS reactor was 7. According to the Fig. $2 a$, pH changes were not statistically significant $(p=0.5)$ and the interquartile range for $P W+S S$ and $P S+S S$ reactors were 2.8 and 0.65 , respectively. Rama et al. in their study concluded that the increase in $\mathrm{pH}$ was from 40 to $70 \%$ and in the final value was between 8 and 9 (Rama \&Vasanthy 2014). Brito et al, in their study reported that pH changes were from 6.9 to 9.9, which was consistent with the results of the present study (Brito et al. 2012).

The $\mathrm{EC}$ is one of the important parameters in the composting process examined during the process. Figure $2 \mathrm{~b}$ shows the EC changes during the composting process in the PW + SS and PS + SS reactors. EC changes in PS + SS reactor had decreasing trend from the beginning (from $6 \mathrm{mmhose} / \mathrm{cm}$ to $2.5 \mathrm{mmhose} / \mathrm{cm}$ ) and in PW + SS reactor initially had an increasing trend (from

$2 \mathrm{mmhose} / \mathrm{cm}$ to $6 \mathrm{mmhose} / \mathrm{cm} 6$ ) and after the 40th day had a decreasing trend (from $6 \mathrm{mmhose} / \mathrm{cm}$ to $3 \mathrm{mmhose} / \mathrm{cm}$ ). According to the figure, EC changes were not statistically significant $(p=0.2)$ and the interquartile ranges for PW + SS and PS + SS reactors were 2.6 and 1.8, respectively. This finding was consistent with the results of Malakotian et al, in which the EC rate decreased from $14.34 \mathrm{ds} / \mathrm{m}$ to $11.91 \mathrm{ds} / \mathrm{m}$ after 30 days (a decreasing trend for pistachios) (Malakootian et al. 2014). However, the present study finding was not in line with Jalili's study, in which the EC rate increased from $1.2 \mathrm{ds} / \mathrm{m}$ to $2.9 \mathrm{ds} / \mathrm{m}$ in the reactor of pistachio waste combined with municipal sewage sludge treatment and decreased from $1.4 \mathrm{ds} / \mathrm{m}$ to $1.3 \mathrm{ds} / \mathrm{m}$ in the reactor of pistachio combined with cattle manure (Jalili et al. 2019).

\section{$\mathrm{C} / \mathrm{N}$ changes}

Figure 3 reveals the $\mathrm{C} / \mathrm{N}$ changes during the composting process in the PW $+\mathrm{SS}$ and $\mathrm{PS}+\mathrm{SS}$ reactors. The $\mathrm{C} / \mathrm{N}$ ratio in the $\mathrm{PW}+$ SS and PS + SS reactors was in the range of 20 to 40 . At the beginning of the process, the $\mathrm{C} / \mathrm{N}$ ratio was 24.5 in the PW $+\mathrm{SS}$ reactor and 37.5 in the PS + SS reactor. $\mathrm{C} / \mathrm{N}$ changes in both reactors had a decreasing trend from 25 to 15 in the PW + SS reactor and from 37 to 23 in the PS + SS reactor. According to Fig. 3, the C/N ratio had further decreased in the PW + SS reactor. The changes were statistically significant $(p \leq 0.001)$ and the interquartile range for $P W+S S$ and $P S+S S$ reactors was 15.75 and 3.5 , respectively and for PW + SS and PS + SS reactors were 7.86 and 1.85 , respectively. The decreasing trend in $\mathrm{C} / \mathrm{N}$ ratio in this study is in consistent with others similar studies (Esmaeili et al. 2020, Jalili et al. 2019). The C/N rate in the PW + SS reactor was in the standard range and the PS + SS reactor needed more time to reach the standard (Brinton 2000).

\section{Percentages of organic carbon and ash}

Figure $4 \mathrm{a}$ shows the changes in the percentage of OC during the composting process of the PW $+\mathrm{SS}$ and PS + SS reactors. The percentage changes of OC in the PW + SS reactor decreased from 69 to 15 and in the PS + SS reactor from 78 to 48 . The trend of changes in OC in both reactors was significantly $(p=0.031)$ decreasing. The interquartile range for PW $+S S$ and PS + SS reactors was 39.45 and 25.1, respectively. The percentage of decomposition and consumption of OC in the PW + SS reactor was higher than the PS + SS reactor. Figure 4b reveals the ash percentage. According to the Fig. 4b, changes in ash percentage showed that ash content in both reactors had an increasing trend from 16 to 28 in the PW + SS reactor and from 16 to 20 in the PS + SS

Page 6/15 
reactor. Changes in ash percentage in the two reactors were significantly increasing $(p=0.038)$ and the interquartile range for PW + SS and PS + SS reactors was 7.74 and 2.39 , respectively.

\section{Heavy metals changes}

Table 2 shows the concentration of heavy metals in the initial composition and final product of composting in the PW + SS and PS + SS reactors. Copper $(\mathrm{Cu})$ concentration in the PW + SS reactor increased from 112 to $161 \mathrm{ppm}$ and in the PS + SS reactor from 206 to $338 \mathrm{ppm}$. According to the Iranian standard, the amount of $\mathrm{Cu}$ is in the range of 90 to 260 , so although it had an increasing trend, it was in the standard range; however, it was not in the standard range in the PS + SS reactor. According to the standard Cu limit in the US EPA, which is a maximum of 100 ppm, both reactors were not within the international standard range. The concentration of $Z n$ in the PW + SS and PS + SS reactors was $(P \leq 0.01)$ and up to the end did not change in both reactors $(P$ $\leq 0 / 01)$. The standard concentration of $\mathrm{Zn}$ in Iran is 800 to $1200 \mathrm{ppm}$, and the concentration of $\mathrm{Zn}$ in both reactors was in the standard range. The maximum standard Zn concentration in the US EPA is $300 \mathrm{ppm}$, which is within the standard range. The amount of iron ( $\mathrm{Fe})$ at the beginning of the process in the $\mathrm{PW}+\mathrm{SS}$ reactor was $0.63 \mathrm{ppm}$ and at the end it was $0.99 \mathrm{ppm}$ and in the PS + SS reactor it initially increased from 1.21 to $1.79 \mathrm{ppm}$. The Iranian standard range of Fe in the compost is 800 to $1500 \%$, so the amount of $\mathrm{Fe}$ in both reactors was less than the standard. The maximum amount of iron in the US EPA standard is 200 $\mathrm{ppm}$, which is within the international standard. Manganese $(\mathrm{Mn})$ concentration in the PW + SS reactor was $0.02 \mathrm{ppm}$ and at the end reached $0.03 \mathrm{ppm}$ and in the PS + SS reactor it was initially $0.03 \mathrm{ppm}$ and at the end reached $0.05 \mathrm{ppm}$. The standard concentration of $\mathrm{Mn}$ in the compost is 2 to $12 \mathrm{ppm}$, so although it had an increasing trend, it was in the standard range. The concentration of lead in the PW + SS reactor at the beginning and end was 8 and 10 ppm, respectively, and in the PS + SS reactor at the beginning and end reached 18 to $31 \mathrm{ppm}$. The maximum concentration of lead in the US EPA standard is $100 \mathrm{ppm}$, which is within the standard range. The concentration of cadmium (Cd) in the PW + SS reactor at the beginning and end of the process was 0.29 and $0.33 \mathrm{ppm}$, respectively, and in the PS + SS reactor at the beginning and end reached 0.32 to $0.41 \mathrm{ppm}$. According to the standard range of Cd concentration in the compost in Iran, which is $10 \mathrm{ppm}$, in both reactors it is in the standard range. The US EPA standard has set 3 as the maximum concentration of $\mathrm{Cd}$, which is within the standard range. The concentration of nickel (Ni) in the PW + SS reactor at the beginning and end of the process was 12 and 50 ppm, respectively, and in the PS + SS reactor it increased from 14 to $21 \mathrm{ppm}$. Iranian standard value for $\mathrm{Ni}$ is $120 \mathrm{ppm}$, so both of them were within the standard range according to the results. The maximum standard Ni concentration in USEPA is 50 ppm, which is within the standard range. Tandy et al, studied heavy metals on composting green and fibrous waste and concluded that composting for more than 26 weeks reduced the availability of $\mathrm{Ni}$, had no effect on $\mathrm{Pb}$, and slightly increased $\mathrm{Cu}$ and $\mathrm{Zn}$. As a result, the total concentrations of $\mathrm{Cu}$ and $\mathrm{Ni}$ in the compost have exceeded the legal guidelines for land use. However, due to their anti-salinity nature, compost poses little threat to soil or plant quality if used for agriculture or land reclamation (Tandy et al. 2009). Wang et al, conducted a study on the use of lime on municipal sewage sludge compost and its effect on heavy metals. They concluded that it reduced nickel, copper, and manganese, but no significant difference was found in the various forms of Pb. However, the residual form of $\mathrm{Pb}$ increased by adding lime, and the predominant form of $\mathrm{Zn}$ was mainly oxidized, and lime further reduced this deformation. Therefore, lime is a suitable substance for composting with municipal sewage sludge to reduce heavy metals (Wang et al. 2013). Fernández et al, pointed out that in the composting process, due to the leachate recirculation and mass loss, the amount of heavy metals is constantly increasing, which should be taken into account (Fernández et al. 2010). The concentration of heavy metals has changed due to the effect of concentration and mass loss after composting (Farrell \&Jones 2009). Bolan et al, reported that the concentration of heavy metals varies with the type of fertilizer, suggesting that plant type may affect composting (Bolan et al. 2004). The mentioned studies are not consistent with the current study. 
Table 2

Heavy metals concentrations at the beginning and end of the composting process in the PW + SS and PS + SS reactors

\begin{tabular}{|lllll|}
\hline Metals (ppm) & Initial (PW + SS reactor) & Final (PW+SS reactor) & Initial (PS + SS reactor) & Final (PS + SS reactor) \\
\hline $\mathrm{Cu}$ & 112 & 161 & 206 & 338 \\
\hline $\mathrm{Mn}$ & 0.02 & 0.03 & 0.03 & 0.05 \\
\hline $\mathrm{Pb}$ & 8 & 10 & 18 & 31 \\
\hline $\mathrm{Cd}$ & 0.29 & 0.33 & 0.32 & 0.41 \\
\hline $\mathrm{Ni}$ & 12 & 50 & 14 & 21 \\
\hline $\mathrm{Zn}$ & $\leq 0.01$ & $\leq 0.01$ & $\leq 0.01$ & $\leq 0.01$ \\
\hline $\mathrm{Fe}$ & 0.63 & 0.99 & 1.21 & 1.79 \\
\hline
\end{tabular}

\section{Toxicity assessment (germination index)}

Table 3 represents changes in the germination index for final compost in PW + SS and PS + SS. In the PS + SS reactor, no dilution was performed for the germination index test and the index percentage was measured with $10 \mathrm{cc}$ of the compost extract, which was 100 in the PS + SS reactor. For the PW + SS reactor, dilution was performed with distilled water. In the PW + SS compost, the index percentage was zero until dilution 4. Dilution 10 means (10 cc of the compost extract), dilution 9 means (9 cc of the compost extract and $1 \mathrm{cc}$ of distilled water), dilution 8 means (8 cc of the compost extract and $2 \mathrm{cc}$ of distilled water), and so on. At a dilution of $1: 9 \%$, the germination index was 100 . In evaluating the toxicity, the PS + SS reactor was better than the PW + SS reactor. Due to changes in germination index percentage, it was not statistically significant $(p=0.2)$. The results showed that PS + SS compost was better than PW + SS compost because the germination index of date-palm straw was $100 \%$. However, the PW + SS reactor after dilution with distilled water showed different percentages at different dilutions. Asses et al, compared municipal sewage sludge compost combined with olive waste and another municipal sewage sludge combined with green waste. The results showed that the germination indices for corn and tomato seeds for the first compost were $79.68 \%$ and $97.36 \%$, respectively and for the second compost were $74.45 \%$ and $81.45 \%$, respectively (Asses et al. 2018). Kebieche et al, studied the effect of sawdust addition on municipal sewage sludge compost and germination index and concluded that the germination index was more than $80 \%$ (Kebibeche et al. 2019).

Table 3

Germination indices in the PW + SS and PS + SS final compost

\begin{tabular}{|lll|}
\hline Final compost & $\begin{array}{l}\text { Dilution } \\
\text { (compost : water) }\end{array}$ & Germination index (\%) \\
\hline PW +SS & $10: 0$ & 0 \\
& $9: 1$ & 0 \\
\hline & $8: 2$ & 0 \\
& $7: 3$ & 0 \\
& $6: 4$ & 4 \\
& $5: 5$ & 12 \\
& $4: 6$ & 30 \\
& $3: 7$ & 60 \\
\hline PS + SS & $2: 8$ & 90 \\
\hline
\end{tabular}




\section{Conclusion}

Date-palm straw wastes were used for the first time in the composting process and were compared with pistachio wastes in a 60day period. A greater increase in temperature was observed in the $\mathrm{PW}+\mathrm{SS}$ reactor. The rate of moisture reduction was higher in the reactor the $\mathrm{PW}+\mathrm{SS}$ reactor compared to the PS + SS reactor. EC changes in both reactors were within the standard range. The $\mathrm{pH}$ value in the PW + SS reactor was in the standard range; however, it was not in the standard range in the PS + SS reactor. In both reactors, the $\mathrm{C} / \mathrm{N}$ ratio had a decreasing trend and in the PW + SS reactor it was in the standard range. It was not in the standard range in the PS + SS reactor and required more time to decompose organic matter. The amount of heavy metals in both reactors had an increasing trend. All metals were within the USEPA standard range, except copper metal which was not in the standard range. The fecal coliform microbial index was $<10^{5}$ at the beginning and reached zero at the end. Toxicity assessment of the final product also showed that PS + SS compost was less toxic than PW + SS. According to the results, the final product quality of the PW + SS reactor was higher than PS + SS; however, the final product toxicity was lower in the PS + SS reactor.

\section{Declarations}

\section{Ethics approval and consent to participate}

Not applicable

\section{Consent for publication}

Not applicable

\section{Availability of data and materials}

Not applicable

\section{Competing interests}

The authors declare that they have no competing interests

\section{Funding}

This study was a part of a master's thesis in Shahid Sadoughi University of Medical Sciences, Yazd, approved with the ethics code of IR.SSU.SPH.REC.1398.034 in 2020.

\section{Authors' contributions}

HJP, MJ, MM and ANH TZ tested and analysis the data. MM, HE, FM and AAE interpreted the data and contribute to writing the paper. All authors read and approved the final manuscript.

\section{Acknowledgments}

This study was a part of a master's thesis in Shahid Sadoughi University of Medical Sciences, Yazd, approved with the ethics code of IR.SSU.SPH.REC.1398.034 in 2020. It was supported by Rafsanjan University of Medical Sciences and Health Services. Thanks are owed to the staff of Sarcheshmeh water treatment plant and those who cooperated in conducting this study.

\section{References}

1. Ahanchi M, Tabatabaei M, Aghbashlo M, Rezaei K, Talebi AF, Ghaffari A, Khoshnevisan B, Khounani Z (2018) Pistachio (Pistachia vera) wastes valorization: enhancement of biodiesel oxidation stability using hull extracts of different varieties. $\mathrm{J}$ Clean Prod 185:852-859

2. Ajmal M, Aiping S, Awais M, Ullah MS, Saeed R, Uddin S, Ahmad I, Zhou B, Zihao X (2020) Optimization of pilot-scale invessel composting process for various agricultural wastes on elevated temperature by using Taguchi technique and 
compost quality assessment. Process Saf. Environ. Prot

3. Asses N, Farhat A, Cherif S, Hamdi M, Bouallagui H (2018) Comparative study of sewage sludge co-composting with olive mill wastes or green residues: Process monitoring and agriculture value of the resulting composts. Process Saf Environ Prot 114:25-35

4. Awasthi MK, Pandey AK, Bundela PS, Khan J (2015) Co-composting of organic fraction of municipal solid waste mixed with different bulking waste: characterization of physicochemical parameters and microbial enzymatic dynamic. Bioresour Technol 182:200-207

5. Bolan N, Adriano D, Mahimairaja S (2004) Distribution and bioavailability of trace elements in livestock and poultry manure by-products. Crit Rev Environ Sci Technol 34:291-338

6. Brinton WF (2000) Compost quality standards and guidelines, Final Report by Woods End Research Laboratories. State Association of Recyclers, for the New York

7. Brito LM, Mourão I, Coutinho J, Smith S (2012) Simple technologies for on-farm composting of cattle slurry solid fraction. Waste Manag 32:1332-1340

8. Calisti R, Regni L, Proietti P (2020) Compost-recipe: A new calculation model and a novel software tool to make the composting mixture. Journal of Cleaner Production, 122427

9. Dhamodharan K, Varma VS, Veluchamy C, Pugazhendhi A, Rajendran K (2019) Emission of volatile organic compounds from composting: A review on assessment, treatment and perspectives. Sci Total Environ 695:133725

10. Esmaeili A, Khoram MR, Gholami M, Eslami H (2020) Pistachio waste management using combined compostingvermicomposting technique: Physico-chemical changes and worm growth analysis. J Clean Prod 242:118523. 10.1016/j.jclepro.2019.118523

11. Farrell M, Jones DL (2009) Heavy metal contamination of a mixed waste compost: metal speciation and fate. Bioresour Technol 100:4423-4432

12. Fernández FJ, Sánchez-Arias V, Rodríguez L, Villaseñor J (2010) Feasibility of composting combinations of sewage sludge, olive mill waste and winery waste in a rotary drum reactor. Waste Manag 30:1948-1956

13. Geethamani R, Soundara B, Kanmani S, Jayanthi V, Subaharini T, Sowbiyalakshmi V, Sowmini C (2020) Production of cost affordable organic manure using institutional waste by rapid composting method. Materials Today: Proceedings https://doi.org/10.1016/j.matpr.2020.02.803

14. Girón-Rojas C, Gil E, Garcia-Ruiz A, Iglesias N, López M (2020) Assessment of biowaste composting process for industrial support tool development through macro data approach. Waste management 105:364-372

15. Hu Z, Liu Y, Chen G, Gui X, Chen T, Zhan X (2011) Characterization of organic matter degradation during composting of manure-straw mixtures spiked with tetracyclines. Bioresour Technol 102:7329-7334

16. Jalili M, Mokhtari M, Ebrahimi A, Boghri F (2016) An Investigation on In-Vessel Composting of Pistachio Residuals with Different Additions. Iranian Journal of Health Environment 9:411-420

17. Jalili M, Mokhtari M, Eslami H, Abbasi F, Ghanbari R, Ebrahimi AA (2019) Toxicity evaluation and management of cocomposting pistachio wastes combined with cattle manure and municipal sewage sludge. Ecotoxicol Environ Saf 171:798804. 10.1016/j.ecoenv.2019.01.056

18. Kebibeche H, Khelil O, Kacem M, Harche MK (2019) Addition of wood sawdust during the co-composting of sewage sludge and wheat straw influences seeds germination. Ecotoxicol Environ Saf 168:423-430

19. Luo Y, Liang J, Zeng G, Chen M, Mo D, Li G, Zhang D (2018) Seed germination test for toxicity evaluation of compost: Its roles, problems and prospects. Waste Manag 71:109-114

20. Malakootian M, Mobini M, Nekoonam GA (2014) Evaluation of the Compost Produced from Mixed Sludge of Municipal Wastewater Treatment Plant and Pistachio Hull Waste. Journal of Mazandaran University of Medical Sciences 24:172-183

21. Meng X, Yan J, Zuo B, Wang Y, Yuan X, Cui Z (2020) Full-scale of composting process of biogas residues from corn stover anaerobic digestion: Physical-chemical, biology parameters and maturity indexes during whole process. Bioresour Technol $302: 122742$ 
22. Mudhoo A, Ramasamy DL, Bhatnagar A, Usman M, Sillanpää M (2020) An analysis of the versatility and effectiveness of composts for sequestering heavy metal ions, dyes and xenobiotics from soils and aqueous milieus. Ecotoxicol Environ Saf 197:110587

23. Rama L, Vasanthy M (2014) Market waste management using compost technology. International Journal of Plant Animal Environmental Sciences(IJPAES) 4:57-61

24. Rashad FM, Saleh WD, Moselhy MA (2010) Bioconversion of rice straw and certain agro-industrial wastes to amendments for organic farming systems: 1. Composting, quality, stability and maturity indices. Bioresour Technol 101:5952-5960

25. Sahu A, Manna M, Bhattacharjya S, Rahman MM, Mandal A, Thakur J, Sahu K, Bhargav V, Singh U, Sahu K (2020) Dynamics of maturity and stability indices during decomposition of biodegradable city waste using rapo-compost technology. Appl Soil Ecol 155:103670

26. Shirani H, Abolhasani Z, Lakzian A, Akhgar A (2011) Decomposition rate of municipal wastes compost, vermi compost, manure and Pistaco compost in different soil texture and salinity in laboratory condition. Journal of watr soil 25:84-93

27. Tandy S, Healey J, Nason M, Williamson J, Jones D (2009) Heavy metal fractionation during the co-composting of biosolids, deinking paper fibre and green waste. Bioresour Technol 100:4220-4226

28. Toledo M, Gutiérrez M, Peña A, Siles J, Martín M (2020) Co-composting of chicken manure, alperujo, olive leaves/pruning and cereal straw at full-scale: Compost quality assessment and odour emission. Process Saf. Environ. Prot

29. Usman AR, Abduljabbar A, Vithanage M, Ok YS, Ahmad M, Ahmad M, Elfaki J, Abdulazeem SS, Al-Wabel MI (2015) Biochar production from date palm waste: charring temperature induced changes in composition and surface chemistry. J Anal Appl Pyrolysis 115:392-400

30. Wang F, Zhao L, Shen Y, Meng H, Xiang X, Cheng H, Luo Y (2013) Analysis of heavy metal contents and source tracing in organic fertilizer from livestock manure in North China. Transactions of the Chinese Society of Agricultural Engineering 29:202-208

31. Xuejiang W, Ling C, Siqing X, Jianfu Z (2008) Changes of Cu, Zn, and Ni chemical speciation in sewage sludge cocomposted with sodium sulfide and lime. J Environ Sci 20:156-160

32. Zhao F, Kang D, Han X, Yang G, Feng Y, Ren G (2015) Soil stoichiometry and carbon storage in long-term afforestation soil affected by understory vegetation diversity. Ecol Eng 74:415-422

33. Zhou X, Hua X, Huang L, Xu Y (2019) Bio-utilization of cheese manufacturing wastes (cheese whey powder) for bioethanol and specific product (galactonic acid) production via a two-step bioprocess. Bioresour Technol 272:70-76

\section{Figures}



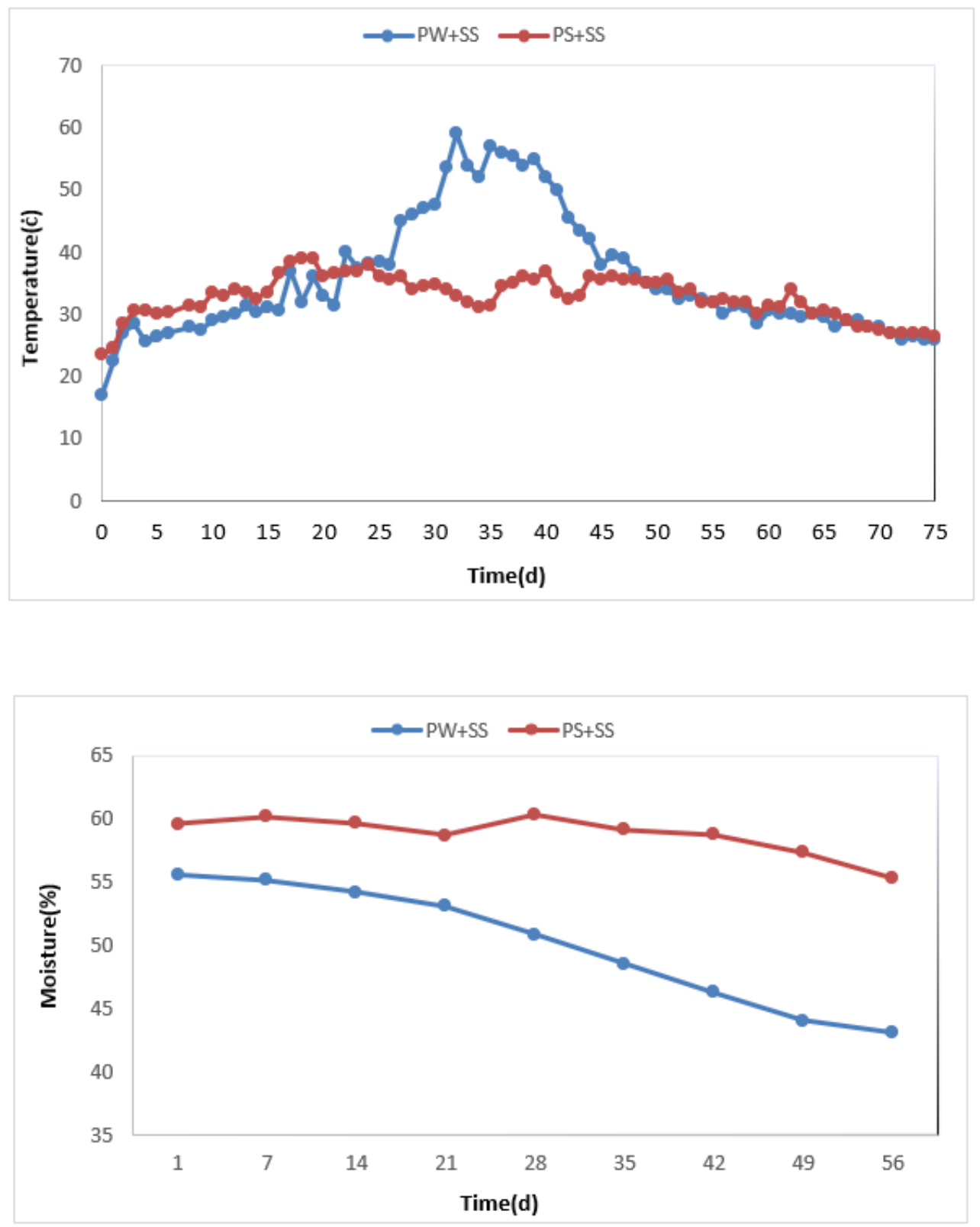

Figure 1

Temperature (a) and humidity (b) changes during composting process in PW+SS and PS+SS reactors 

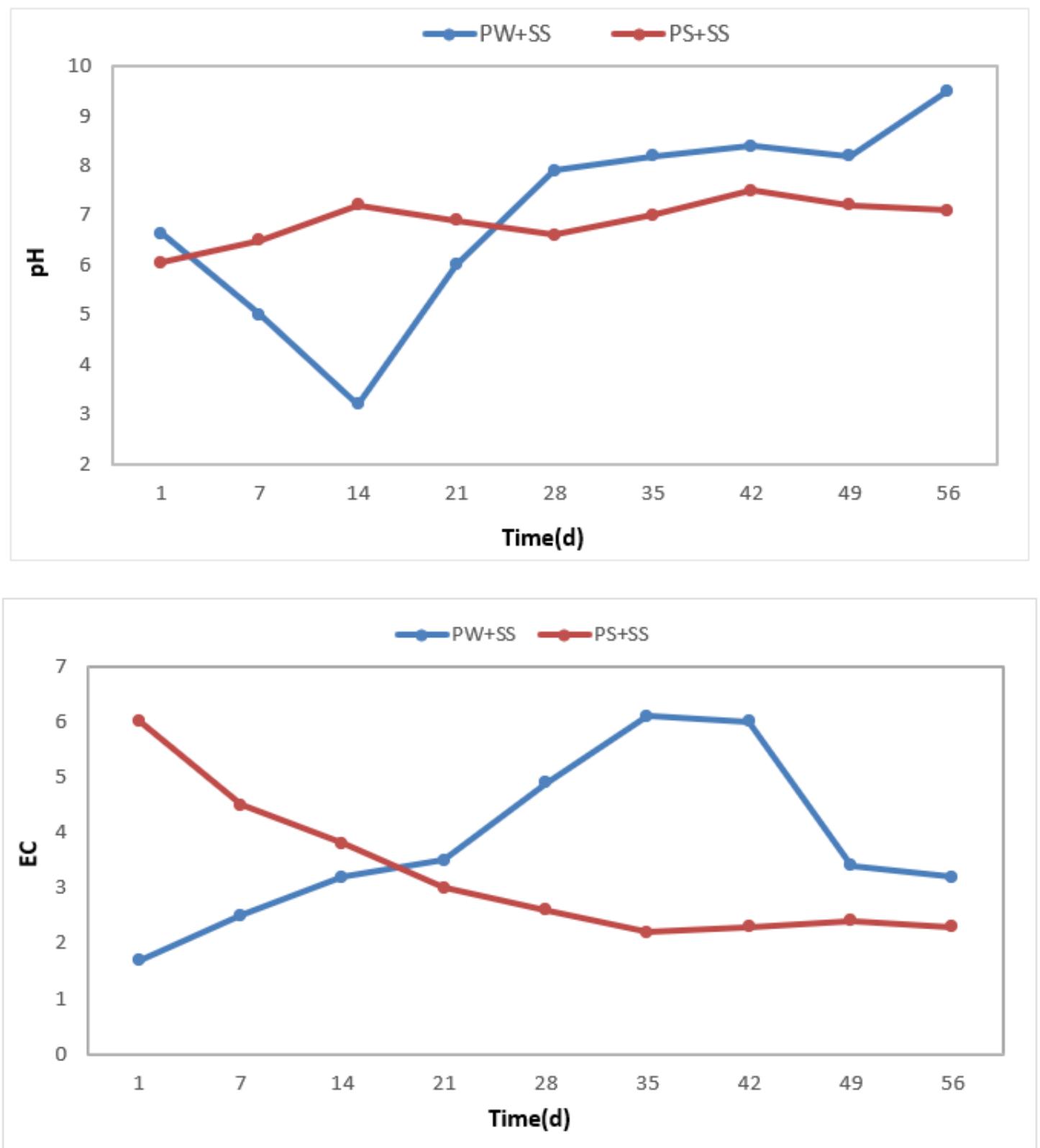

Figure 2

$\mathrm{pH}(\mathrm{a})$ and EC (b) changes during the composting process of the PW+SS and PS+SS reactors 


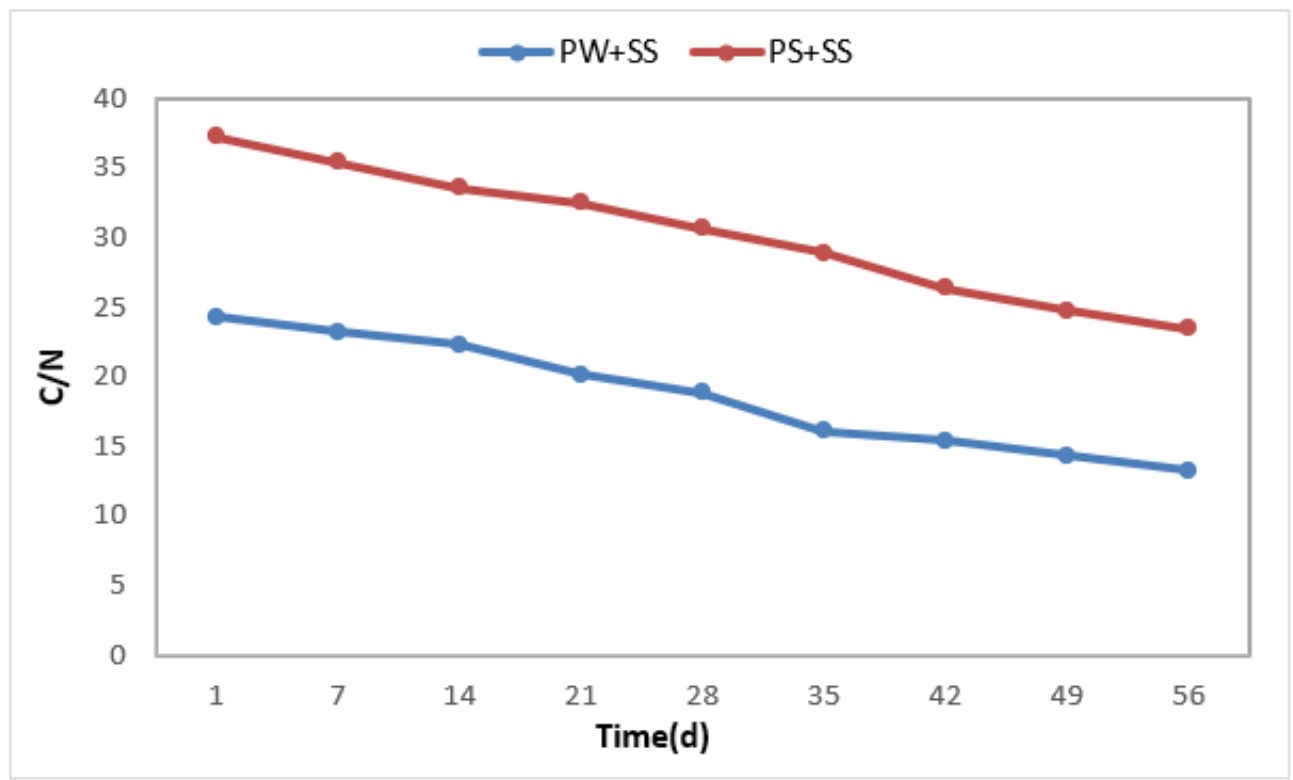

Figure 3

$\mathrm{C} / \mathrm{N}$ ratio changes during the composting process of the $\mathrm{PW}+\mathrm{SS}$ and $\mathrm{PS}+\mathrm{SS}$ reactors 

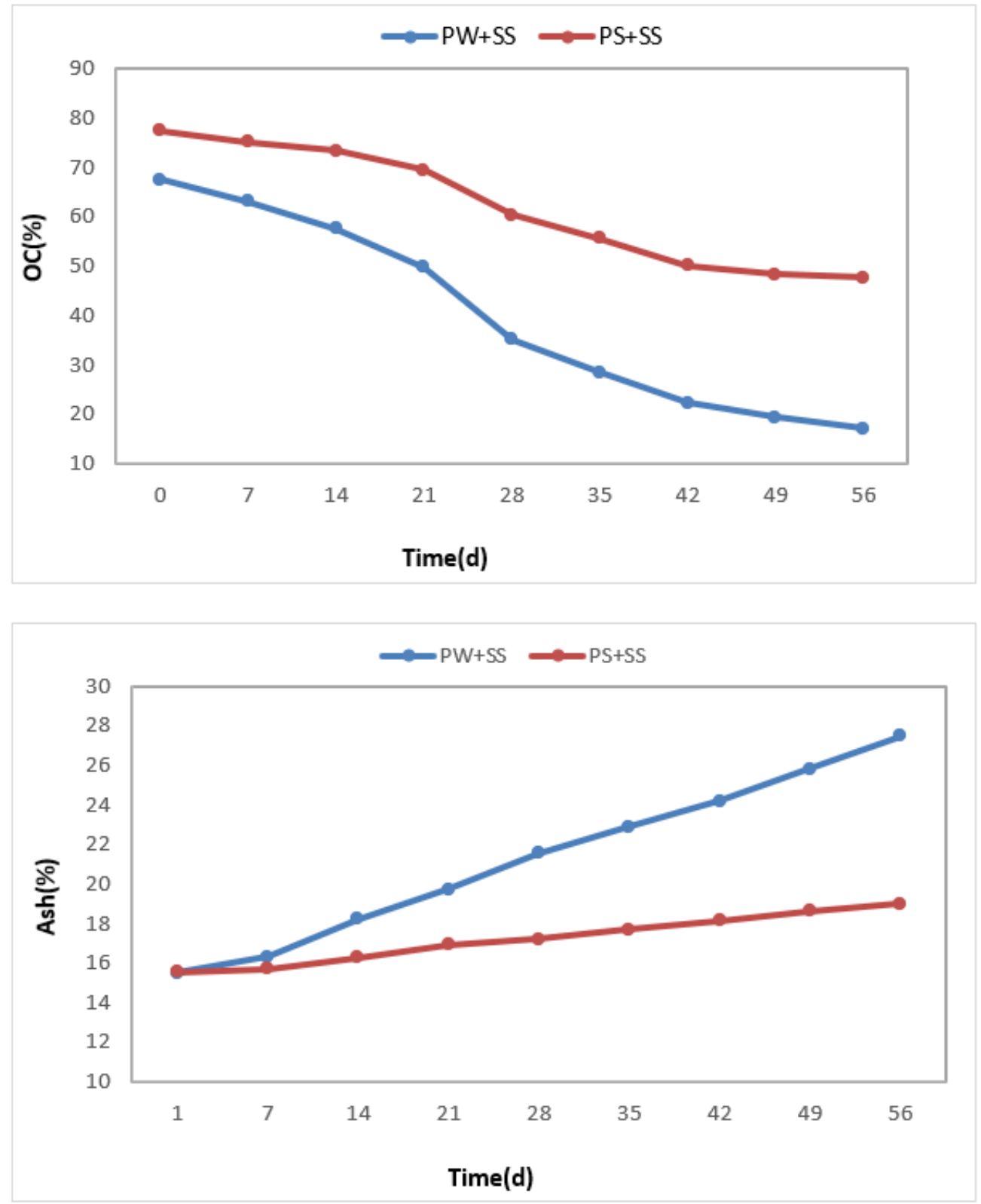

Figure 4

Changes in the organic carbon (a) and ash (b) percentage during the composting process of the PW+SS and PS+SS reactors 